\title{
EFFECT OF DIFFERENT LIGAND AND DIFFERENT LIGAND HETEROMETAL XYLARATOHERMANATES ON THE ACTIVITY OF $\alpha$-L-RHAMNOSIDASES OF EUPENICILLIUM ERUBESCENS, CRYPTOCOCCUS ALBIDUS AND PENICILLIUM TARDUM
}

\author{
O.V. Gudzenko ${ }^{1}$, N.V. Borzova ${ }^{1}$, L.D. Varbanets ${ }^{1}$, \\ I.I. Seifullina ${ }^{2}$, O.A. Chebanenko' ${ }^{2}$ O.E. Martsinko ${ }^{2}$ \\ 'Zabolotny Institute of Microbiology and Virology, NAS of Ukraine, \\ 154 Acad. Zabolotny Str., Kyiv, 03143, Ukraine \\ ${ }^{2}$ I.I. Mechnikov Odessa National University, \\ 2 Dvoryanskaya Str., Odessa, 65029, Ukraine \\ e-mail:varbanets_imv@ukr.net
}

$\alpha$-L-Rhamnosidase [EC 3.2.1.40], enzyme of the hydrolase family has a wide range of applications: in the food industry, for example, in winemaking to improve the quality and aroma of wines, in the production of citrus juices and drinks to remove bitter components (naringin) that improves the quality and nutritional value of these products; in research as an analytical tool for studying the structure of complex carbohydrate-substituted biopolymers. For the successful use of $\alpha$-L-rhamnosidases in various biotechnological processes, an important aspect is the development of ways to increase their activity. The main factors affecting the growth and metabolism of microorganisms, including the synthesis of enzymes, are the physicochemical conditions of cultivation, the composition of the nutrient medium, the introduction of substances that raise the yield of the enzyme, which is manifested in an increase in its activity. At present, one of the priority directions of modern research is the study of the effect of various effector compounds that are capable to modify the studied enzymatic activity. In this work, which is a continuation of previous studies, a number of mixed-ligand and mixed-ligand-different-metal coordination germanium compounds of with xylaric acid (H5Xylar), 1,10-phenanthroline (Phen), 2,2-bipyridine (bipy) and ions of 3d-metals $\left(\mathrm{Fe}^{2+}, \mathrm{Ni}^{2+}, \mathrm{Cu}^{2+}, \mathrm{Zn}^{2+}\right)$ were selected as effectors. Study of the effect of these complexes on the activity of Eupenicillium erubescens, Cryptococcus albidus and Penicillium tardum $\alpha$-L-rhamnosidases were the aim of this work. Materials and methods. The objects of research were $\alpha-L$ rhamnosidases from Eupenicillium erubescens 248, Cryptococcus albidus 1001, and Penicillium tardum IMV F-100074. The $\alpha$-L-rhamnosidase activity was determined by the Davis method using naringin as a substrate. We used 12 coordination compounds of germanium as modifiers of enzyme activity, the composition and structure of which were established using a combination of physical and chemical research methods: elemental analysis, thermogravimetry, IR spectroscopy and X-ray structural analysis. Structures of seven compounds are deposited in the Cambridge Crystallographic Database. When studying the effect of various compounds on the activity of enzymes, concentrations of 0.1 and $0.01 \%$ were used, exposure times were 0.5 and 24 hours. The test compounds were dissolved in $0.1 \%$ dimethyl sulfoxide $U V$-spectra of absorption of native and chemical modified preparations of the enzymes were studied by spectrophotometer-fluorimeter DeNovix DS-11 in the range of 220-340 nm, concentration of the enzyme preparation $1.0 \mathrm{mg}$ of protein $/ \mathrm{mL}$. Results. Analysis of the totality of the obtained data (exposure time $24 \mathrm{~h}$, concentration $0.1 \%$ ) regarding the effect of the studied compounds on the activity of E. erubescens, C. albidus and P. tardum $\alpha$-L-rhamnosidases showed that the influence of the studied modifiers for the activity of $\alpha$-L-rhamnosidases varies depending on the producer strain. Our data allow us to present the following series of modifiers in accordance with an increase in their effect on the activity of enzymes of different producers: E. erubescens: $12<11<5<3<4=10<1<3<8<2<6<7$; C. albidus: $10<11<12<9<3<1=5<8=4<2<6<7$; P. tardum: $12=2<3<4<11<5<8<1<9<$ $6<10<7$. Conclusions. The results obtained allow us to conclude that compound (7)(-tris(bipyridine) nickel(II) $\mu$-dihydroxyxylaratogermanate(IV)) is the most effective activator of $\alpha$-L-rhamnosidases of all three micromycete strains, compound (6)(tris(phenanthroline)nickel(II) $\mu$-dihydroxyxylaratogerman 
ate(IV)) - on $\alpha$-L-rhamnosidase from E. erubescens and C. albidus, while compound (10)-(copper(II) $\mu$-dihydroxyxylaratogermanate(IV)-cuprate(II)) - only of P. tardum $\alpha$-L-rhamnosidase.

Keywords: Eupenicillium erubescens 248, Cryptococcus albidus 1001, Penicillium tardum IMV F-100074, $\alpha$-L-rhamnosidase, different ligand and different ligand heterometal xylaratohermanates, 1,10-phenanthroline, 2,2-bipyridine.

Glycosidases, enzymes of the hydrolase family (O-glycoside hydrolases), which catalyze the hydrolysis of O-glycosidic bonds in glycosides, oligo-, polysaccharides, glycolipids and other glycoconjugates are of particular interest to researchers. Among them is $\alpha$-L-rhamnosidase ( $\alpha$-L-rhamnoside-rhamnohydrolase, EC 3.2.1.40), which hydrolytically cleaves the terminal unreduced $\alpha-1,2, \alpha-1,4$ and $\alpha-1,6$ bound residues of L-rhamnose in natural products such as naringin, rutin, quercetrin, hesperidin and other rhamnosecontaining glycosides [1]. $\alpha$-L-Rhamnosidase has a wide range of applications: in the food industry, for example, in winemaking to improve the quality and aroma of wines, in the production of citrus juices and drinks to remove bitter components (naringin) that improves the quality and nutritional value of these products; in research as an analytical tool for studying the structure of complex carbohydratesubstituted biopolymers. For the successful use of $\alpha$-L-rhamnosidases in various biotechnological processes, an important aspect is the development of ways to increase their activity. The main factors affecting the growth and metabolism of microorganisms, including the synthesis of enzymes, are the physicochemical conditions of cultivation, the composition of the nutrient medium, the introduction of substances that raise the yield of the enzyme, which is manifested in an increase in its activity. Previously, we studied the effect of hydroxycarboxylatohermanates with protonated forms of 1,10-phenanthroline, 2,2'-bipyridine and their complexes with 3d-metals on the activity of Eupenicillium erubescens 248, Cryptococcus albidus 1001 and Penicillium tardum IMV F-100074 $\alpha$-L-rhamnosidases [2, 3]. Most of the complexes were characterized by an activating effect, and some of them by an inhibiting one, in contrast to the inorganic salts $\mathrm{Cu}^{2+}, \mathrm{Ni}^{2+}, \mathrm{Fe}^{2+}, \mathrm{Zn}^{2+}$, $\mathrm{Pb}^{2+}, \mathrm{Hg}^{2+}$, which manifested themselves only as inhibitors $[4,5]$. At present, one of the priority directions of modern research is the study of the effect of various effector compounds that are capable to modify the studied enzymatic activity.

In this work, which is a continuation of previous studies, a number of mixed-ligand and mixed- ligand-different-metal coordination germanium compounds with xylaric acid (H5Xylar), 1,10-phenanthroline (Phen), 2,2-bipyridine (bipy) and ions of 3d-metals were selected as effectors $\left(\mathrm{Fe}^{2+}, \mathrm{Ni}^{2+}\right.$, $\left.\mathrm{Cu}^{2+}, \mathrm{Zn}^{2+}\right)$. Study of the effect of these complexes on the activity of E. erubescens, C. albidus and P. tardum $\alpha$-L-rhamnosidases were the aim of this work.

Materials and methods. The objects of research were $\alpha$-L-rhamnosidases from E. erubescens 248, C. albidus 1001, and P. tardum IMV F-100074. Preparations of $\alpha$-L-rhamnosidases were obtained from the supernatant of culture liquids of E. erubescens [6], C. albidus [7] and P. tardum [8] by precipitation with ammonium sulfate to $90 \%$ saturation, followed by gel permeation and ion exchange chromatography on Toyopearl HW60 ("Toyo Soda", Japan) and Fractogel DEAE650-s ("Merck", Germany), respectively.

The $\alpha$-L-rhamnosidase activity was determined by the Davis method [9] using naringin as a substrate.

As modifiers of enzyme activity, we used 12 coordination germanium compounds: (1) protonated phenanthroline with $\mu$-dihydroxyxylaratogermanate(IV) ((HPhen $)_{4}\left[(\mathrm{OH})_{2} \mathrm{Ge}_{2}(\mu-\mathrm{HXy}-\right.$ lar) $\left.\left.{ }_{4} \mathrm{Ge}_{2}(\mu-\mathrm{OH})_{2}\right] \cdot 13 \mathrm{H}_{2} \mathrm{O}\right),(2)$ bis(phenanthroline) chlorocopper(II) with $\mu$-dihydroxyxylaratogermanate(IV) $\left(\left[\mathrm{CuCl}(\mathrm{Phen})_{2}\right]_{4}\left[(\mathrm{OH})_{2} \mathrm{Ge}_{2}(\mu-\mathrm{HXylar})_{4}\right.\right.$ $\left.\left.\mathrm{Ge}_{2}(\mu-\mathrm{OH})_{2}\right] \cdot 8 \mathrm{H}_{2} \mathrm{O}\right)$, (3) tris(phenanthroline) copper(II) $\mu$-dihydroxyxylaratogermanate(IV) $\left(\left[\mathrm{Cu}(\mathrm{Phen})_{3}\right]_{2}\left[(\mathrm{OH})_{2} \mathrm{Ge}_{2}(\mu \text {-HXylar })_{4} \mathrm{Ge}_{2}(\mu-\right.\right.$ $\left.\mathrm{OH})_{2}\right] \cdot 8 \mathrm{H}_{2} \mathrm{O}$ ), (4) tris(bipyridine)copper(II) $\mu$-dihydroxyxylaratogermanate(IV) ([Cu(bipy $\left.)_{3}\right]_{2}\left[(\mathrm{OH})_{2} \mathrm{Ge}_{2}(\mu-\mathrm{HXylar})_{4} \mathrm{Ge}_{2}(\mu-\mathrm{OH})_{2}\right]$. $14 \mathrm{H}_{2} \mathrm{O} \cdot 2 \mathrm{C}_{2} \mathrm{H}_{5} \mathrm{OH}$ ), (5) tris(bipyridine)zinc $\mu$-dihydroxyxylaratogermanate(IV) ([Zn(bipy $\left.)_{3}\right]_{2}\left[(\mathrm{OH})_{2} \mathrm{Ge}_{2}(\mu-\mathrm{HXylar})_{4} \mathrm{Ge}_{2}(\mu-\mathrm{OH})_{2}\right]$. $\left.18 \mathrm{H}_{2} \mathrm{O} \cdot 2 \mathrm{C}_{2} \mathrm{H}_{5} \mathrm{OH}\right)$, (6) tris(phenanthroline) nickel(II) $\mu$-dihydroxyxylaratogermanate(IV) $\left(\left[\mathrm{Ni}(\mathrm{Phen})_{3}\right]_{2}\left[(\mathrm{OH})_{2} \mathrm{Ge}_{2}(\mu-\mathrm{HXylar})_{4} \mathrm{Ge}_{2}(\mu-\right.\right.$ $\left.\mathrm{OH})_{2}\right] \cdot 8 \mathrm{H}_{2} \mathrm{O}$ ), (7) tris(bipyridine)nickel(II) $\mu$-dihydroxyxylaratogermanate (IV) ([Ni(bipy $\left.)_{3}\right]_{2}\left[(\mathrm{OH})_{2} \mathrm{Ge}_{2}(\mu-\mathrm{HXylar})_{4} \mathrm{Ge}_{2}(\mu-\mathrm{OH})_{2}\right.$ ]$\left.\cdot 20 \mathrm{H}_{2} \mathrm{O} \cdot 2 \mathrm{C}_{2} \mathrm{H}_{5} \mathrm{OH}\right), \quad(8)$ tris(bipyridine) 
iron(II) $\mu$-dihydroxyxylaratogermanate(IV) $\left(\left[\mathrm{Fe}(\text { bipy })_{3}\right]_{2}\left[(\mathrm{OH})_{2} \mathrm{Ge}_{2}(\mu-\mathrm{HXylar})_{4} \mathrm{Ge}_{2}(\mu-\right.\right.$ $\left.\left.\mathrm{OH})_{2}\right] \cdot 12 \mathrm{H}_{2} \mathrm{O} \cdot 2 \mathrm{C}_{2} \mathrm{H}_{5} \mathrm{OH}\right),(9)$ tris(phenanthroline) iron(II) $\mu$-dihydroxyxylaratogermanate(IV) $\left(\left[\mathrm{Fe}(\mathrm{Phen})_{3}\right]_{2}\left[(\mathrm{OH})_{2} \mathrm{Ge}_{2}(\mu-\mathrm{HXylar})_{4} \mathrm{Ge}_{2}(\mu-\right.\right.$ $\left.\left.\mathrm{OH})_{2}\right] \cdot 6 \mathrm{H}_{2} \mathrm{O} \cdot \mathrm{C}_{2} \mathrm{H}_{5} \mathrm{OH}\right)$, (10) copper(II) $\mu$-dihydroxyxylaratogermanate(IV)-cuprate(II) $\left(\left[\mathrm{Cu}\left(\mathrm{H}_{2} \mathrm{O}\right)_{6}\right]\right.$ $\left.\left[\mathrm{Ge}\left(\mu_{3}-\mathrm{Xylar}\right)_{2}\left\{\mathrm{Cu}\left(\mathrm{H}_{2} \mathrm{O}\right)_{2}\right\}_{2}\right] \cdot 2 \mathrm{H}_{2} \mathrm{O}\right),(11)$ nickel(II) $\mu$-dihydroxyxylaratogermanate(IV)-nickelate(II) $\left(\left[\mathrm{Ni}\left(\mathrm{H}_{2} \mathrm{O}\right)_{6}\right]\left[\mathrm{Ge}\left(\mu_{3}-\mathrm{Xylar}\right)_{2}\left\{\mathrm{Ni}\left(\mathrm{H}_{2} \mathrm{O}\right)_{2}\right\}_{2}\right] \cdot 2 \mathrm{H}_{2} \mathrm{O}\right)$, (12) zinc $\mu$-dihydroxyxylaratogermanate(IV)-zincate $\left(\left[\mathrm{Zn}\left(\mathrm{H}_{2} \mathrm{O}\right)_{6}\right]\left[\mathrm{Ge}\left(\mu_{3} \text {-Xylar }\right)_{2}\left\{\mathrm{Zn}\left(\mathrm{H}_{2} \mathrm{O}\right)_{2}\right\}_{2}\right]\right.$. $\left.\cdot 2 \mathrm{H}_{2} \mathrm{O}\right)$.

The composition and structure of these compounds was established using a combination of physical and chemical research methods: elemental analysis, thermogravimetry, IR spectroscopy and $\mathrm{X}$-ray structural analysis [10-12]. Structures of seven compounds are deposited in the Cambridge Crystallographic Database: 1883675 (1), 1999455 (2), 1999453 (3), 1883677 (6), 1569267 (7), 1569266 (8), $1883676(9)$.

All complexes are cation-anionic compounds. In 1-9, the same homometallic tetrameric $\mu$-dihydroxyxylaratogermanate anion $\left[(\mathrm{OH})_{2} \mathrm{Ge}_{2}\right.$ $\left.(\mu-\mathrm{HXylar})_{4} \mathrm{Ge}_{2}(\mu-\mathrm{OH})_{2}\right]$ is realized, and in $10-$ 12 the heterometallic three-nuclear anion [Ge $\left.(\mu 3 \text {-Xylar })_{2}\left\{\mathrm{M}\left(\mathrm{H}_{2} \mathrm{O}\right)_{2}\right\}_{2}\right]^{2}$. The anion charge is compensated for by the following cations: protonated 1,10-phenanthroline $\left(\mathrm{HPhen}^{+}\right)$ molecules (1), 3d-metal complex cations (2-9), and 3d-metal hexaaquacations (10-12). Schemes of compounds structures are shown in Fig. 1.

When studying the effect of various compounds on the activity of enzymes, concentrations of 0.1 and $0.01 \%$ were used, exposure times were 0.5 and 24 hours. The test compounds were dissolved in $0.1 \%$ of dimethyl sulfoxide (DMSO). UV-spectra of absorption of native and chemical modified preparations of the enzymes were studied by spectrophotometer-fluorimeter DeNovix DS-11 in the range of $220-340 \mathrm{~nm}$, concentration of the enzyme preparation was $1.0 \mathrm{mg}$ of protein $/ \mathrm{mL}$.

All experiments were carried out in seven replicates. The analysis of the obtained results was carried out by statistical processing using the Student's t-test. In the work, the mean values and standard errors $(\mathrm{M} \pm \mathrm{m})$ were calculated. Values at $\mathrm{p}<0.05$ were considered significant. The results, which are shown graphically, were processed using Microsoft Excel 2007.
Results. Preparations of $\alpha$-L-rhamnosidases were obtained from the supernatant of culture liquids of three producers: E. erubescens, C. albi$d u$ and $P$. tardum. The specific $\alpha$-L-rhamnosidase activity of the preparations was $120 \mathrm{U} / \mathrm{mg}$ protein for $E$. erubescens, $12 \mathrm{U} / \mathrm{mg}$ protein for $C$. albidus and $27 \mathrm{U} / \mathrm{mg}$ protein for P. tardum (protein content $-0.01 \mathrm{mg} / \mathrm{mL}$ ).

As modifiers of enzyme activity, 12 above mentioned related compounds were used. They are fine-crystalline precipitates of different colors, stable in air, and do not hydrolyze. In solutions, they dissociate with the formation of the corresponding cations and anions (Fig. 1).

Studies have shown that at a concentration of $0.01 \%$, almost all germanium compounds at different exposure times did not affect the $\alpha$-L-rhamnosidase activity of $E$. erubescens (Fig. 2 A, B). The only exception is compound (1), upon exposure to which for 1 hour the activity was at the control level and with the raise in the exposure time to 24 hours, an increase in activity was observed by $35 \%$.

A more pronounced effect was observed when using the compounds at a concentration of $0.1 \%$.

Compounds (2), (4), (5), (8), and (9), when exposed to the enzyme for 1 hour (Fig. 2A), insignificantly activated $E$. erubescens $\alpha$-L-rhamnosidase (by $6-17 \%$ ). While compounds (1), (6), (7) and (10) increased activity to a greater extent (by $129 \%$ (1) and (6) compounds, by $76 \%$ - (7) compound and by $60 \%-(10)$ compound).

An increase in the exposure time (Fig. 2B) promoted an increase in the activating effect of compounds (2)-(9). At the same time, the activating effect of compounds (1) and (10), on the contrary, decreased with increasing of the exposure time. Compounds (11) and (12) (Fig. 2 A, B) had no effect on the activity of the studied $\alpha$-L-rhamnosidase. The activity was at the control level at different times of action and different concentrations.

It should be noted the greatest activating effect of compound (7) at a concentration of $0.1 \%$. At an exposure time of 1 hour with this compound (Fig. 2A), $\alpha$-L-rhamnosidase activity increased by $76 \%$, while an increase in the exposure time to 24 hours (Fig. 2B) promoted an increase of E. erubescens $\alpha$-L-rhamnosidase activity by 9.7 times. The maximum activation of $C$. albidus $\alpha$-L-rhamnosidases was also observed under the 


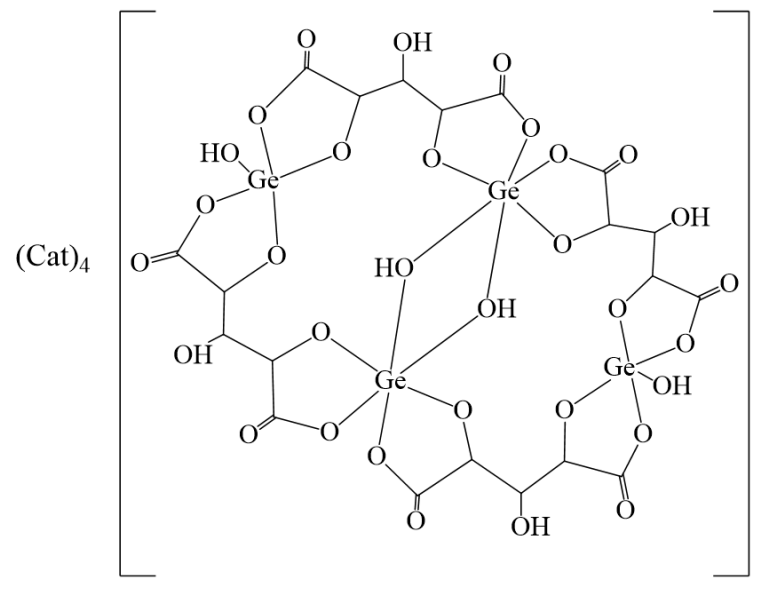

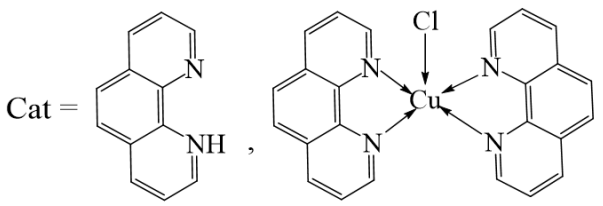

(1)

(2)

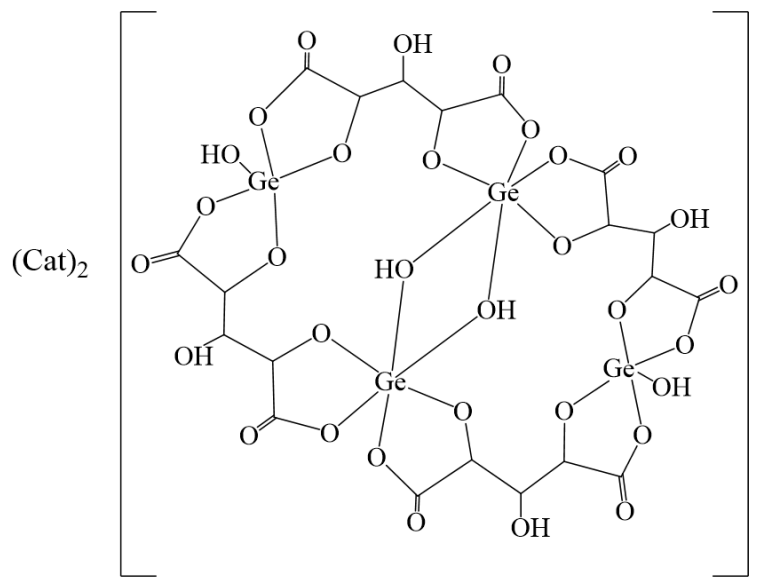
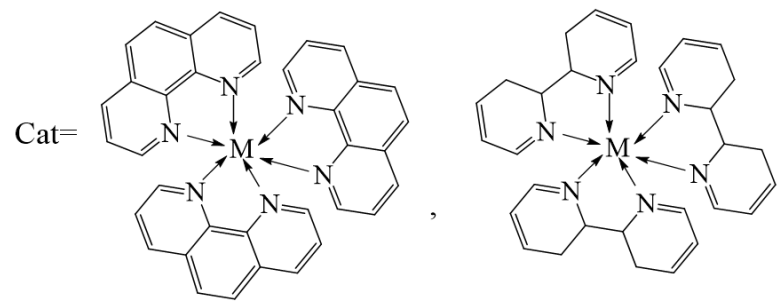

$\mathrm{M}=\mathrm{Cu}(\mathbf{3}), \mathrm{Ni}(\mathbf{6}), \mathrm{Fe}(\mathbf{9})$

$\mathrm{M}=\mathrm{Cu}(\mathbf{4}), \mathrm{Zn}(\mathbf{5}), \mathrm{Ni}(\mathbf{7}), \mathrm{Fe}(\mathbf{8})$
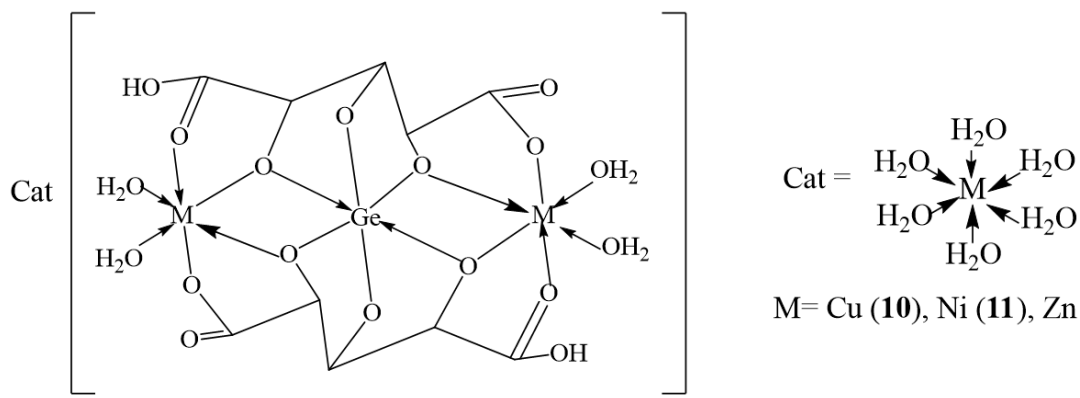

$\mathrm{M}=\mathrm{Cu}(\mathbf{1 0}), \mathrm{Ni}(\mathbf{1 1}), \mathrm{Zn}$ (12)

F i g. 1. Schemes of structures 1-12 
action of compound (7) at a concentration of $0.1 \%$ (Fig. 3 A, B). With an increase in the exposure time to 24 hours (Fig. 3B), an increase in the activating effect was found almost twofold (from 320 to $600 \%)$. Thus, the effect of all compounds, besides (7), on C. albidus $\alpha$-L-rhamnosidase was less significant than the effect on E. erubescens $\alpha$-Lrhamnosidase. A different nature of the interaction is also observed. If, in the case of E. erubescens $\alpha$-L-rhamnosidase, an increase in the exposure time promoted an increase in the activating action of compounds (2)-(9) (Fig. 2B), then in the case of $C$. albidus $\alpha$-L-rhamnosidase, on the contrary, compounds (3)-(6) and (8), (9) with a shorter exposure time (Fig. 3A), the studied enzyme was activated to a greater extent. The exceptions were compounds (2) and (7), which, as in the case of
$\alpha$-L-rhamnosidase from E. erubescens, exhibited greater activation with an increase in the time of influence. Similar results were noted under the action of compounds (10)-(12).

Studies of the influence of germanium coordination compounds on the activity of $P$. tardum $\alpha$-L-rhamnosidase showed that at a concentration of $0.01 \%$ with an exposure time of 1 hour (Fig. 4A), only compound (7) increased the activity by $25 \%$. While an increase in the exposure time to $24 \mathrm{~h}$ (Fig. 4B) at the same concentration of compounds promoted an increase in the activity of $P$. tardum $\alpha$-L-rhamnosidase by compounds (8), (10) and (11).

The study of the effect of high concentrations of compounds $(0.1 \%)$ on the activity of $P$. tardum $\alpha$-L-rhamnosidase showed (Fig. 4 A, B) that the

A

$=0,01 \% \quad 0,10 \%$
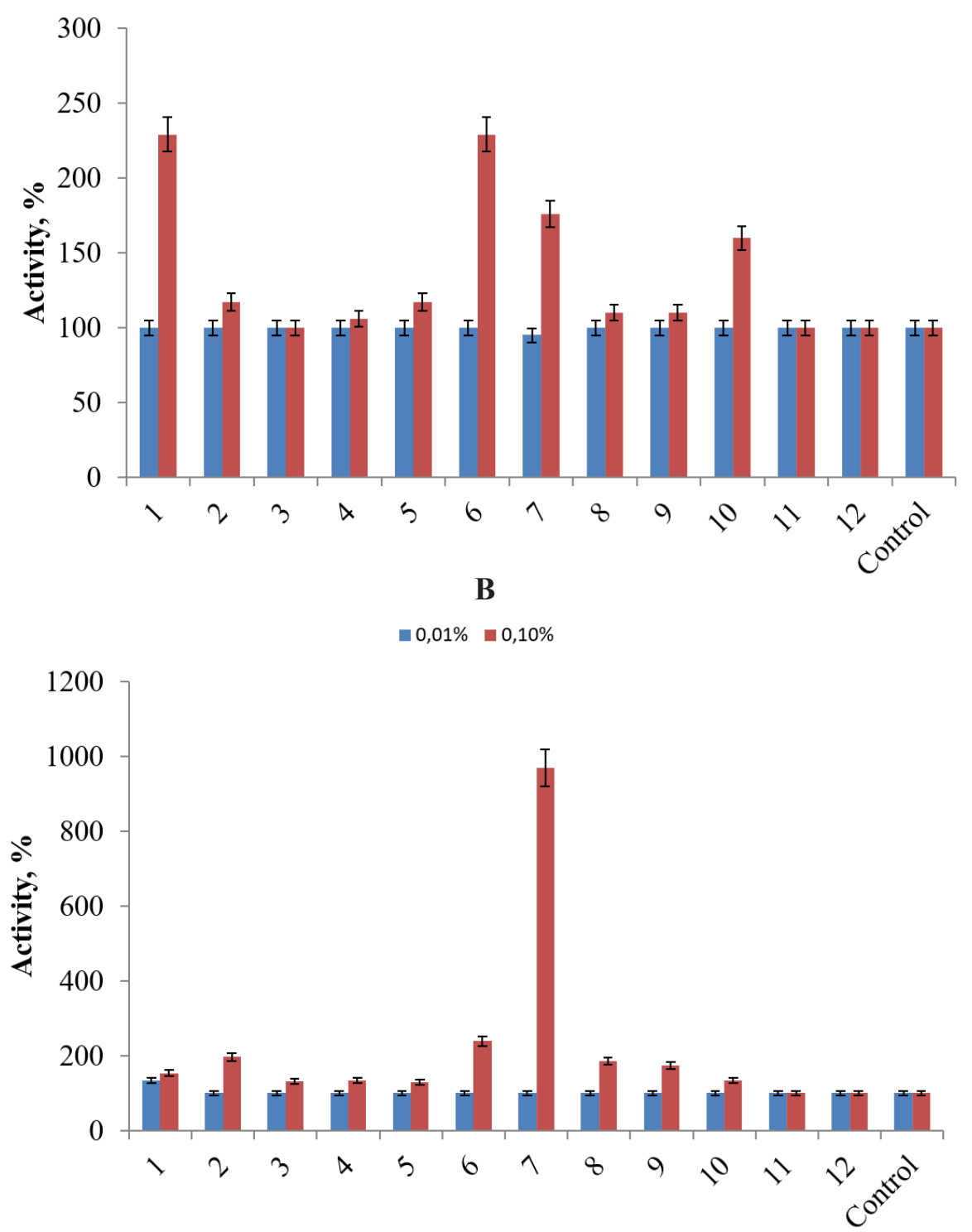

$F$ i g. 2. Influence of germanium compounds on the activity of $E$. erubescens $\alpha$-L-rhamnosidase: A- exposure time 1 hour; B - exposure time 24 hours 
stimulating effect of compounds (5)-(11) increases with increasing of exposure time, and compounds (1), on the contrary, decreased. Compounds (2), (3), (4), and (12) at different exposure times and concentrations did not affect the activity of $P$. tardum $\alpha$-L-rhamnosidase.

Thus, compound (7) exhibited the greatest activating effect on $\alpha$-L-rhamnosidases of all three producers, compound (6) - on $\alpha$-L-rhamnosidase from $E$. erubescens and C. albidus, while compound (10) - only to $P$. tardum $\alpha$-L-rhamnosidase.

The study of UV absorption spectra of native proteins and proteins in the presence of various compounds, in particular metals and their complexes, can provide some answers regarding the nature of their interaction [13]. In all cases, in the presence of compound (7), two absorption peaks were observed at 295 and $245 \mathrm{~nm}$ (Fig. 5). Absorption in the $230-300 \mathrm{~nm}$ wavelength range is mainly provided by the contribution of the residues of aromatic amino acids tryptophan, tyrosine and phenylalanine, and, to some extent, at $260 \mathrm{~nm}$ by the existing disulfide bonds [14]. It was shown that the absorption intensity increases with an increase in the concentration of compound (7) for all $\alpha$-Lrhamnosidases. This may indicate insignificant topological changes in the enzyme molecule as a result of breaking hydrogen bonds or be caused by the adsorption of the protein on the surface of the complex as a result of the binding of protein chromophores to the free carbonyl and carboxyl groups of the compound (7). The result of this interaction is the change in catalytic activity of the studied $\alpha$-L-rhamnosidases.

Thus, based on the differences in the degree of influence of various complex compounds on the activity of the studied enzymes, we can assume a different arrangement of aromatic amino acid residues and their accessibility to $\alpha$-Lrhamnosidases from E. erubescens, C. albidus, and $P$. tardum, which provides conformational and catalytic uniqueness of enzymes from different producer.

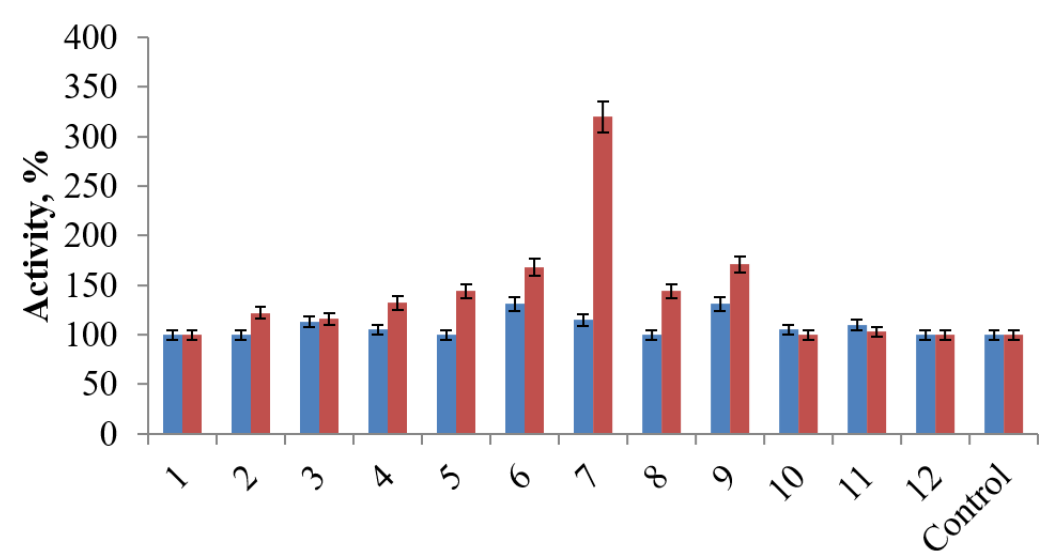

B

च $0,01 \% \quad \square 0,10 \%$

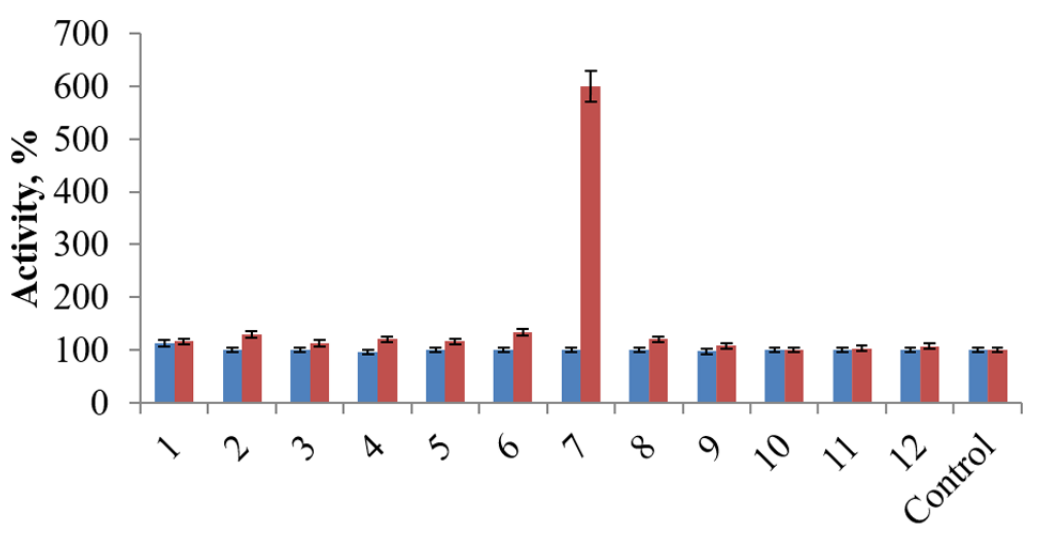

F i g. 3. Influence of germanium compounds on the activity of $C$. albidus $\alpha$-L-rhamnosidase: A-exposure time 1 hour; B - exposure time 24 hours 


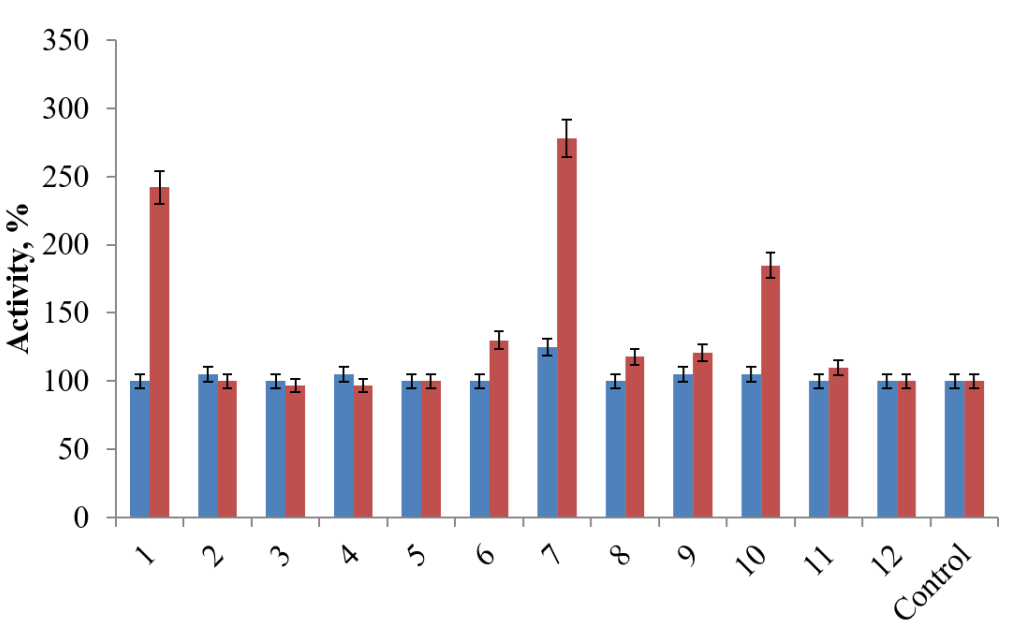

B

$=0,01 \%=0,10 \%$

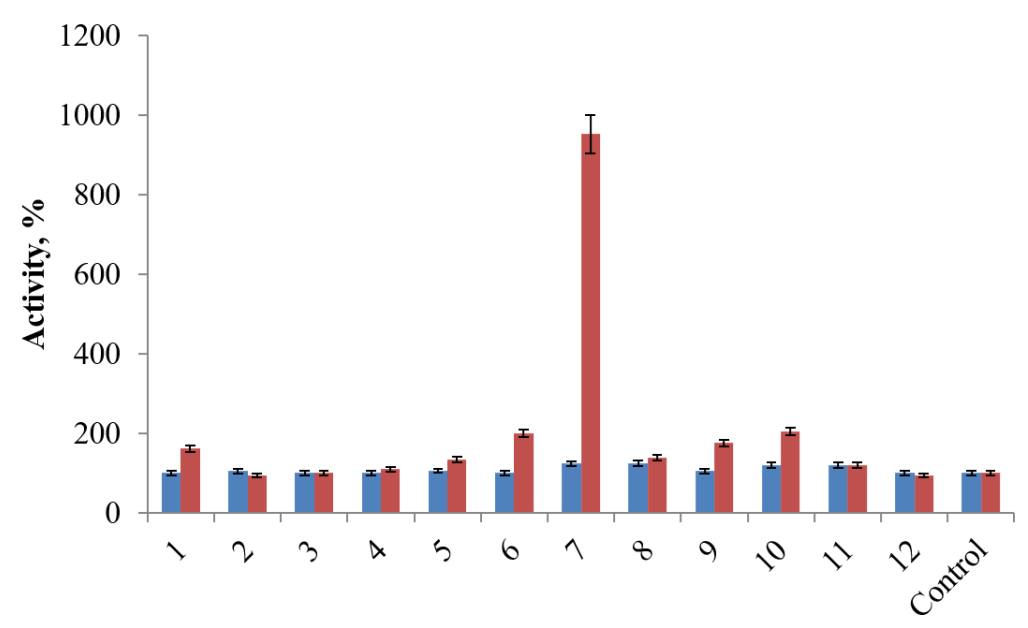

F i g. 4. Influence of germanium compounds on the activity of $P$. tardum $\alpha$-L-rhamnosidase: A - exposure time 1 hour; B - exposure time 24 hours

Discussion. The widespread use of $\alpha$-L-rhamnosidase for solving current chemical-technological, biological-medical problems stimulates the interest of researchers in the search for compounds that can control their catalytic activity. In this regard, special attention is attracted to biocoordination complexes, similar to those existing in natural biosystems. Biocomplexes of this type based on essential Germanium (IV), a second biometals $\left(\mathrm{Na}^{+}, \mathrm{K}^{+}, \mathrm{Ca}^{2+}, \mathrm{Mg}^{2+}, \mathrm{Fe}^{2+}\right.$, $\mathrm{Co}^{2+}, \mathrm{Ni}^{2+}, \mathrm{Cu}^{2+}, \mathrm{Zn}^{2+}$ ) and hydroxycarboxylic acids (citric, malic, tartaric, xylaric acids) widely used in medicine, food industry as ligands, were first synthesized by us [2-5]. Most of these compounds refer to low toxic substances with a wide spectrum of pharmacological action: antiviral, immunomodulatory, antimicrobial, antioxidant, antihypoxant, neurotropic, etc. [15, 16]. Complexes of germanium, cobalt, and nickel metals with organic ligands have also proven themselves as promising activators of enzymes $[17,18]$. However, the question of the mechanism of interaction of metal complexes with proteins, and enzymes in particular, remains unclear.

Analysis of the totality of the obtained data (exposure time $24 \mathrm{~h}$, concentration $0.1 \%$ ) regarding the effect of the studied compounds on the activity of E. erubescens, C. albidus and P. tardum $\alpha$-L-rhamnosidases showed that the nature of the influence of the studied modifiers for the activity of $\alpha$-L-rhamnosidases varies depending on the producer strain. Our data allow us to present the following series of modifiers in accordance with an increase in their effect on the activity of enzymes of different producers: $E$. erubescens: $12<11<5<3<$ $4=10<1<3<8<2<6<7$; C. albidus: $10<11<$ $12<9<3<1=5<8=4<2<6<7$; P. tardum: $12=2<3<4<11<5<8<1<9<6<10<7$. 
The differences between these rows are due to the fact that the studied enzymes have different functional groups and conformational structures, which affect the nature and degree of binding with the modifier. In addition, for each row, the dependence of the modifier activity on the synergism of the action of a set of biologically active molecules constituting them is typical.

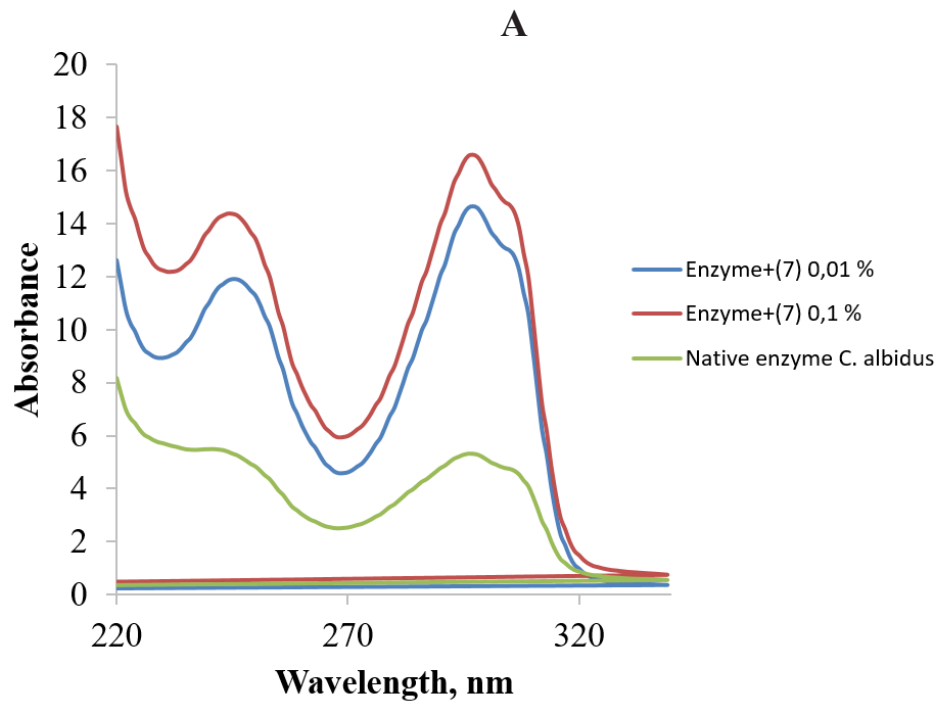

B

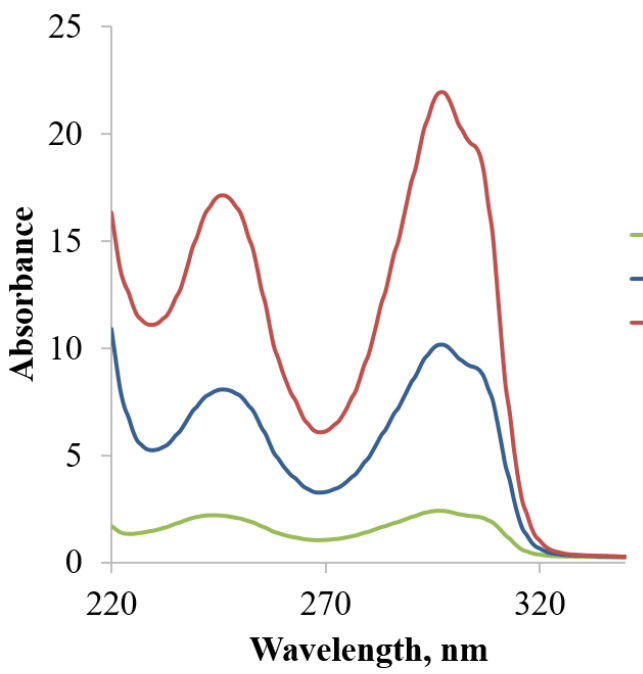

C

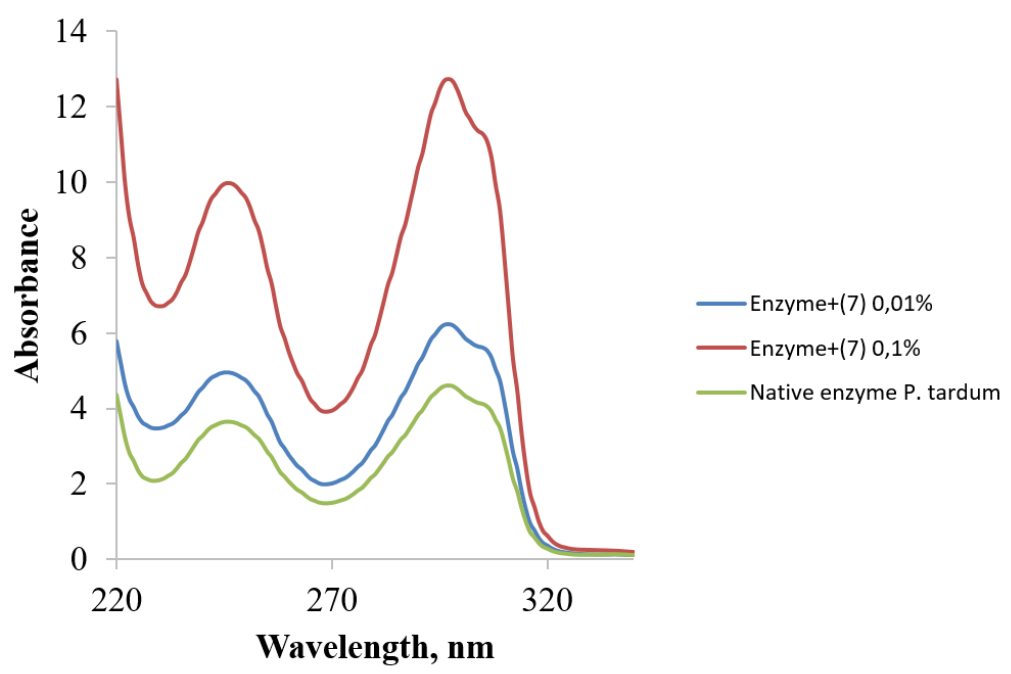

F i g. 5. UV absorption spectra of native $\alpha$-L-rhamnosidases of $C$. albidus (A), E. erubescens (B) and $P$. tardum (C), as well as enzymes under the action of compound (7) 
The results obtained allow us to conclude that compound (7) is the most effective activator of $\alpha$-L-rhamnosidases of all three micromycete strains. At a concentration of $0.1 \%$ and an exposure time of $1 \mathrm{~h}$, an increase in the activity of enzymes was noted: E. erubescens by 9.7 times, C. albidus by 6 times and P. tardum by 9.5 times. Compound (6) ranks second in efficiency. It should be noted that these modifiers are characterized by the composition of their molecules (Fig. 1) by the presence of different heterocyclic amines: $6-$ 1,10-phenanthroline, 7 -2,2'-bipyridine.

It is their participation in the intra- and intermolecular $\pi-\pi$ stacking interaction that explains the high activity of compounds (6), (7), which increases in the case of the latter due to the effect of size: 1,10-phenanthroline is a bulkier, bulky ligand than 2,2'-bipyridine (Fig. 1). Complexes 10-12, unlike the others, do not contain secondary ligands (1,10-phenanthroline, 2,2'-bipyridine), their complex anion is heterometallic (Fig. 1). They differ from each other only in the presence of different metals: $\mathrm{Cu}$ (10), Ni (11), Zn (12).

The ability of compound (10) to exert a stimulating effect on the activity of P. tardum $\alpha$-Lrhamnosidase is probably related to the presence of $\mathrm{Cu}^{2+}$, although the nature of their interaction is difficult to explain, since this enzyme is not a metalloenzyme.

Analysis of UV spectra of solutions of native enzymes and enzymes in the presence of complex (7) allows us to draw some conclusions about the nature of their interaction. For all enzymes, hyperchronism was noted in the regions of 220 , 245 and $295 \mathrm{~nm}$ with increasing concentration of the compound. An increase in UV absorption in the range of $180-230 \mathrm{~nm}$ is usually associated with the changes in the $\mathrm{n} \rightarrow \pi^{*}$ interaction of protein chains. This non-covalent interaction is of great importance for stabilizing the structures of biomolecules and materials, although its strength is usually very weak [19]. The increase in absorption at 245 and $295 \mathrm{~nm}$ indicates changes associated with the contribution of aromatic amino acids and disulfide bonds. Apparently, no strong covalent bonds of the enzyme with the studied compounds are formed. This is evidenced by the removal of the activating effect after dialysis. The observed activation of enzymes is most likely realized through connections with regulatory regions of allosteric fragments, and not with active centers. As a result, the reacting groups of the substrate and the enzyme come closer together, that is, their complementarity is induced, which contributes to an increase in the rate of hydrolysis.

Thus, based on the peculiarities in the degree of influence of complex compounds on the activity of the studied enzymes, we can assume a different arrangement of aromatic amino acid residues and their accessibility for $\alpha$-L-rhamnosidases from E. erubescens, C. albidus, and P. tardum, which provides conformational and catalytic uniqueness of enzymes from various sources. The results obtained allow us to recommend the investigated complex compounds (6), (7), (10) for obtaining active forms of $\alpha$-L-rhamnosidases.

Conclusions. The results obtained allow us to conclude that compound (7)(-tris(bipyridine) nickel(II) $\mu$-dihydroxyxylaratogermanate(IV)) is the most effective activator of $\alpha$-L-rhamnosidases of all three micromycete strains, compound (6)(tris (phenanthroline)nickel(II) $\mu$-dihydroxyxylaratoge rmanate(IV)) - of $\alpha$-L-rhamnosidase from E. erubescens and C. albidus, while compound (10- copper(II) $\mu$-dihydroxyxylaratogermanate(IV)-cuprate(II)) - only of $P$. tardum $\alpha$-L-rhamnosidase.

\section{ВПЛИВ РІЗНОЛІГАНДНИХ ТА РІЗНОЛІГАНДНО-ГЕТЕРОМЕТАЛЬ- НИХ КСИЛАРАТОГЕРМАНАТІВ НА АКТИВНІСТЬ $\alpha$-L-РАМНОЗИДАЗ EUPENICILLIUM ERUBESCENS, CRYPTOCOCCUS ALBIDUS I PENICILLIUM TARDUM}

\author{
О.В. Гудзенко ${ }^{1}$ Н.В. Борзова ${ }^{1}$, \\ Л.Д. Варбанець ${ }^{1}$, І.І. Сейфулліна ${ }^{2}$, \\ О.А. Чебаненко ${ }^{2}$, О.Е. Марцинко ${ }^{2}$
}

${ }^{1}$ Інститут мікробіології і вірусології ім. Д.К. Заболотного НАН Украӥни, вул. Академіка Заболотного, 154, Київ, 03143, Україна

${ }^{2}$ Одеський національний університет ім. I.I. Мечникова, вул. Дворянська, 2, Одеса, 65029, Україна

Резюме

$\alpha$-L-Рамнозидаза [КФ 3.2.1.40], фермент родини гідролаз, має широкий спектр застосування: у харчовій промисловості, наприклад, у виноробстві для покращення якості та аромату вин, у виробництві цитрусових соків та напоїв для видалення гірких компонентів (нарингін), що покращує якість та харчову цінність цих продуктів; у дослідженнях як аналітичний інструмент для вивчення структури складних вуглеводних біополімерів. Для 
успішного використання $\alpha$-L-рамнозидаз у різних біотехнологічних процесах важливим аспектом $\epsilon$ розробка способів підвищення їх активності. Основними факторами, що впливають на ріст i метаболізм мікроорганізмів, включаючи синтез ферментів, є фізико-хімічні умови вирощування, склад живильного середовища, введення речовин, які підвищують вихід ферменту, що виявляється у збільшенні його активності. На сьогодні одним iз пріоритетних напрямків сучасних досліджень $€$ вивчення впливу різних ефекторних сполук, здатних модифікувати досліджувану ферментативну активність. У цій роботі, яка $є$ продовженням попередніх досліджень, ряд різнолігандних та різнолігандно-гетерометальних германатів із ксиларовою кислотою (H5Xylar), 1,10-фенантроліном, 2,2- біпіридином та іонами 3d-металів $\left(\mathrm{Fe}^{2+}, \mathrm{Ni}^{2+}, \mathrm{Cu}^{2+}\right.$, $\mathrm{Zn}^{2+}$ ) були обрані як ефектори. Метою роботи було дослідити вплив ряду різнолігандних та різнолігандно-різнометальних координаційних сполук германію з ксиларовою кислотою (H5Xylar), 1,10фенантроліном (Phen), 2,2-біпіридином (bipy) та йонами $3 \mathrm{~d}$-металів $\left(\mathrm{Fe}^{2+}, \mathrm{Ni}^{2+}, \mathrm{Cu}^{2+}, \mathrm{Zn}^{2+}\right)$ на активність $\alpha$-L-рамнозидаз Eupenicillium erubescens 248 , Cryptococcus albidus 1001 та Penicillium tardum IMB F-100074. Матеріали та методи. Об'єктами дослідження були $\alpha$-L-рамнозидази Eupenicillium erubescens 248, Cryptococcus albidus 1001 та Penicillium tardum IMB F-100074. Активність $\alpha$-Lрамнозидази визначали методом Девіса з використанням нарингіну в якості субстрату. Як модифікатори ферментативної активності були використані 12 координаційних сполук германію, склад і будова яких були встановлені за допомогою фізико-хімічних методів дослідження: елементарного аналізу, термогравіметрії, ІЧ-спектроскопії та рентгеноструктурного аналізу. Структури семи сполук зберігаються в Кембриджській кристалографічній базі даних. При вивченні впливу

1. Yadav V, Yadav PK, Yadav S, Yadav KDS. Alpha-L-rhamnosidase: a review. Proc Biochem. 2010; 45(8):1226-1235. doi:10.1016/j.procbio.2010.05.025

2. Gudzenko OV, Varbanets LD, Seifullina II, Martsinko EE, Pirozhok OV, Chebanenko EA. Germanium coordination compounds for increasing of $\alpha$-L-rhamnosidase activity. Biotechnologia Acta. 2019; 12(4):19-26. різних сполук на активність ферментів використовували концентрації 0,1 та 0,01 \%, час експозиції становив 0,5 та 24 години. Досліджувані сполуки розчиняли в 0,1% диметилсульфоксидуЕ УФ-спектри поглинання нативних та хімічно модифікованих препаратів ферментів вивчали на спектрофотометрі-флуориметрі DeNovix DS-11 в діапазоні 220-340 нм, концентрація ферментного препарату - 1,0 мг білка/мл. Результати. Аналіз сукупності отриманих даних (час експозиції 24 год, концентрація - 0,1%) щодо впливу досліджуваних сполук на активність $\alpha$-L-рамнозидаз E. erubescens, C. albidus та P. tardum показав, що вплив досліджуваних модифікаторів на активність $\alpha$-L-рамнозидаз змінюється залежно від штаму продуцента. Наші дані дозволяють представити наступний ряд модифікаторів відповідно до посилення їх впливу на активність ферментів різних продуцентів: E. erubescens: $12<11<5<$ $3<4=10<1<3<8<2<6<7$; C. albidus: $10<11<12<9<3<1=5<8=4<2<6<7$; P. tardum: $12=2<3<4<11<5<8<1<9<$ $6<10<7$. Висновки. Виявлено особливості впливу досліджених сполук на активність $\alpha-\mathrm{L}-$ рамнозидаз різних продуцентів. Так, встановлено, що сполука (7) - трис (біпіридин) нікель (II) $\mu$-дигідроксиксиларатогерманат (IV) є найефективнішим активатором $\alpha$-L-рамнозидаз усіх трьох штамів мікроміцетів, сполука (6) - трис (фенантролін) нікель (II) $\mu$-дигідроксиксиларатогерманат (IV) - $\alpha$-L-рамнозидази E. erubescens та C. albidus, тоді як сполука (10) - мідь (II) $\mu$-дигідроксиксиларатогерманат (IV) купрат (II) лише $\alpha$-L-рамнозидази P. tardum.

Ключові слова: Eupenicillium erubescens 248, Cryptococcus albidus 1001, Penicillium tardum IMB F-100074, $\alpha$-L-рамнозидаза, різнолігандно-гетерометальні ксиларатогерманати, 1,10-фенантролін, 2,2’-біпіридин.

3. Gudzenko OV, Varbanets LD, Seifullina II, Chebanenko EA, Martsinko EE, Afanasenko EV. The influence of coordinative tartrate and malatogermanate compounds on the activity of $\alpha$-L-rhamnosidase preparations from Penicillium tardum, Eupenicillium erubescens and Cryptococcus albidus. Ukr Biochem J. 2020; 92 (4 ):85-95. https://doi.org/10.15407/ubj92.04.085 
4. Varbanets LD, Matselyukh OV, Nidyalkova NA, Avdiyuk EV, Gudzenko EV, Seifullina II, Masanovets GN, Khitrich NV. [The coordination compounds of cobalt (II, III) with dithiocarbamic acid derivatives - modificators of hydrolytic enzymes activity]. Biotechnologia Acta. 2013; 6(1):73-80. Ukrainian.

5. Seifullina II, Khitrich GN. Coordinative compounds of zinc with n-substituted thiocarbamoil-N'- pentamethylensulfenamides - activity modifiers of enzymes of proteolytic and glycolytic action. Ukr Biochem Z. 2011; 83(3):25-36.

6. Varbanets LD, Gudzenko OV, Borzova NV. Rhamnosidase from Eupenicillium erubescens: purification and characterization. Nauka i Studia. 2013; 41(109):11-23.

7. Borzova N, Gudzenko O, Varbanets L. Purification and characterization of a naringinase from Cryptococcus albidus. Applied biochemistry and biotechnology. 2018; 184(3):953-969. DOI 10.1007/s12010-017-2593-2

8. Gudzenko OV, Varbanets LD. [Purification and physico-chemical properties of $\alpha$-L-rhamnosidase Penicillium tardum]. Mikrobiol Z. 2016; 78(1):13-22. Ukrainian.

9. Davis DW. Determination of flavonones in citrus juice. Anal Biochem. 1947; 19:476-478.

10. Chebanenko EA, Seifullina II, Martsinko EE, Dyakonenko VV, Shishkina SV. Directed Structure Formation in Tetranuclear Xylaratogermanates(IV) with Complex Phenanthrolinecopper(II) Cations. Russian Journal of Inorganic Chemistry. 2020; 65(11):1703-1711. https://doi.org/10.1134/ S0036023620110029

11. Chebanenko EA, Seifullina II, Martsinko EE, Dyakonenko VV, Shishkina SV. Synthesis and Structure of Frame Xylaratogermanate Salts with Protonated Phenanthroline and Its Complexes with Fe(III) and Ni(II) as Cations. Russian Journal of Inorganic Chemistry. 2019; 64(9):1132-1137. https://doi. org/10.1134/S0036023619090043

12. Chebanenko EA, Martsinko EE, Seifullina II, Dyakonenko VV, Shishkina SV. Structural Features
And Properties of Heteronuclear Germanium (IV) and Some 3d Metal Complexes with Xylaric Acid and 2,2'-Bipyridine. Journal of Structural Chemistry. 2018; 59(6):1462-1469. https://link.springer.com/article/10.1134/S0022476618060318

13. Lucas LH, Ersoy BA, Kueltzo LA, Joshi SB, Brandau DT, Thyagarajapuram N, Peek LJ, Middaugh CR. Probing protein structure and dynamics by second-derivative ultraviolet absorption analysis of cation $-\pi$ interactions. Protein Science. 2006; 15:2228-2243.

14. Antosiewicz JM, Shugar D. UV-Vis spectroscopy of tyrosine side -groups in studies of protein structure. Part 2: selected applications. Biophys Rev. 2016; 8:163-177. doi 10.1007 / s12551016-0197-7.

15. Pramodini Devi S, Hemakumar Singh RK, Kadam RM. Synthesis and spectroscopic studies on copper(II) binuclear complexes of 1-phenylamidino-O-alkylurea (alkyl=n-propyl, n- and iso-butyl) with 1,3-diaminopropane or ethylenediamine. Inorg Chem. 2006; 45(5):2193-2918.

16. Debnath A, Hussain F, Masram DT. Synthesis, characterization and antifungal studies of metalloquinolone [Cd2(nal)2(phen)2(Cl)2]; Complex Metals. 2014; 1(1):96-102. DOI:10.1080/21642 32X.2014.889581

17. Tezuka T, Higashino A, Akiba M, Nakamura T. Organogermanium (Ge-132) suppresses activities of stress enzymes responsible for active oxygen species in monkey liver preparation. A. E. R. 2017; 5(2):1323.

18. Ali MM, Noaman E, Kamal S, Soliman S, Ismail DA. Role of germanium L-cysteine $\alpha$-tocopherol complex as stimulator of some antioxidant defense systems in gamma-irradiated rats. Acta Pharm. 2007; 57:1-12. doi: 10.11648/j. jdmp.20160206.16

19. Singh SK, Das A. The $n \rightarrow \pi *$ interaction: a rapidly emerging non-covalent interaction. Phys Chem Chem Phys: PCCP. 2015; 17(15):95969612. DOI: $10.1039 / \mathrm{c} 4 \mathrm{cp} 05536 \mathrm{e}$.

Received 28.01.2021 